\title{
여수프로젝트 성과로 본 해양수산 ODA 시사점
}

최 지 원 (KOICA 기후변화환경실 전문관)

\section{목 차}

1. 들어가며

2. 해양수산ODA 현황

3. 여수프로젝트의 추진현황 및 시사점

4. 맺으며

\section{1. 들어가며}

2012년 한국에서 여수세계박람회가 개최되면서 해양에 대한 국내 및 국제적 관심과 인식이 점차 증대되고 있다. 반기문 유엔 사무총장은 "기후변화 대처와 식량자원 공급에 많은 역할을 하는 바다의 보전을 위해 전 인류가 함께 노력을 기울여야 한다" 고 말했고 리우 +20 에서도 해 양선언을 채택, 해양의 중요성을 국제적으로 지지하고 있다.

이에 따라 여수세계박람회의 개최와 함께 시작된 여수프로젝트는 개도국을 대상으로 한 박 람회 역사상 최초의 해양분야 ODA사업이자 이의 성과를 가시적으로 도출할 수 있는 주요 수 단으로 여겨짐으로써 국내외적으로 관심이 증대되고 있는 상황이다. 코이카는 여수프로젝트 사업 수행을 위해 “여수조직위원회(현 여수재단)"와 수탁계약을 체결, 2010년부터 현재(2013 년)까지 총 24건의 사업1)을 진행한 바 있다 본 원고에서는 코이카에서 여수프로젝트 외 기

1) 1 차 사업의 경우 총 12 건으로 초청연수 5 건, 연구사업 7건 (2010 2012), 2 차 사업의 경우 그레나다, 탄자니아, 스리랑카 에서 개발컨설팅사업 총 3건 (2011 2013), 3차 사업의 국제기구협력사업 6건 (2011 2013), 4차에서는 베트남, 인도네 시아, 필리핀에서 개발컨설팅 사업 총 3 건이 추진되었다. 
수행했던 해양수산분야 ODA현황을 간략하게 소개하고 현재까지 진행된 24건의 여수프로젝트 의 추진내용 및 성과를 정리, 공유하고 향후 해양수산 ODA 사업의 기획 및 수행 관련 시사점 을 제공하고자 한다.

\section{2. 해양수산 ODA의 현황}

148 개의 DAC 협력국 중 100 여개국이 바다와 접한 연안국이며 이러한 연안국의 경우 대부 분 기후변화 및 자연재해에 취약하고 식량 및 소득창출에 있어 해양생태계에 의존도가 상대적 으로 높아 기후변화대응, 연안계획 및 수산자원의 관리기법 등 관련 분야의 수요가 점차 증가 하고 있다.

\section{가. 해양수산 ODA 현황}

〈표 2-1〉 해양분야 ODA2)

\begin{tabular}{l|l}
\hline & \multicolumn{1}{|c}{ 사업명 } \\
\hline 1 & 중국황해유입물 오염측정 및 통제연구 사업 (2008-2010/50만불) \\
\hline 2 & 인도네시아 기후변화 대응을 위한 해안보호 및 관리정책사업 (2010-2011/300만불) \\
\hline 3 & 중국황해오염방지를 위한 유역관리 연구사업 (2011-2013/80만불) \\
\hline 4 & $\mathrm{IMO}$ 동아시아지역 선박온실가스 저감 역량 강화 사업(2011-2013/70만불) \\
\hline
\end{tabular}

해양분야 ODA사업의 경우 코이카는 1994년부터 연수생 초청연수사업을 시작, 2008년부터 는 ‘중국 황해유입물 오염측정 및 통제연구 사업’ 등 프로젝트형 사업을 추진하였다. 해양분야 의 경우 코이카 5 대 중점사업분야(교육, 보건, 농림수산, 공공행정 등)에 포함되지 않고 '환경 및 기타분야'에 분류, 이로 인해 중점분야에 비해 프로젝트형 사업이 활발하지 않은 경향이 있 었으나 2000년 이후 점차 규모를 확대하여 나가고 있다. 2005년 이후 지원실적을 살펴보면 아래 표〈2-3〉과 같이 약 881만불(93억원) 규모이다.

2) $\mathrm{KOICA}$ 사업 토대로 작성 
〈표 2-2〉 수산분야 ODA 규모 (프로젝트 실적 위주, KOICA)

\begin{tabular}{c|c}
\hline & 사업명 \\
\hline 1 & 튀니지 패류양식 기술지원 (2008-2009/160만불) \\
\hline 2 & 알제리 보리새우양식장 건설 및 기술이전 사업 (2008-2010/240만불) \\
\hline 3 & 알제리 사하라사막 새우양식센터 건립 및 양식기술이전 사업 (2010-2014/600만불) \\
\hline
\end{tabular}

수산분야 ODA사업의 경우, 유상 및 무상원조가 있지만 대부분 무상원조사업을 중심으로 진 행되었으며3) 개도국 (연안국)에게 있어 식량 및 단백질의 보급원이자 수산양식을 통한 소득창 출 및 빈곤퇴치가 가능함에 따라.KOICA 5 대 중점지원사업 '농림수산분야' 에 포함되어 지원 되고 있다. 1993년부터 자메이카 새우양식지원사업 (22만불)을 시작으로 2000년 이후에〈표 $2-3>$ 와 같이 규모만 약 1,000 만불 (115억원)이 지원되었다.

\section{〈표 2-3〉 연도별 지원실적 (2005-2012)4)}

(단위 : 백만원)

\begin{tabular}{c|r|r|r|r|r|r|r|r}
\hline & \multicolumn{1}{c|}{2005} & \multicolumn{1}{c|}{2006} & \multicolumn{1}{c|}{2007} & \multicolumn{1}{c}{2008} & \multicolumn{1}{c}{2009} & \multicolumn{1}{c}{2010} & 2011 & \multicolumn{1}{c}{2012} \\
\hline 전체 ODA & 215,120 & 184,881 & 251,086 & 305,541 & 355,747 & 524,731 & 451,840 & 501,338 \\
\hline $\begin{array}{c}\text { 해양수산 } \\
\text { 합계 }\end{array}$ & 509 & 525 & 508 & 2,941 & 5,172 & 5,807 & 3,071 & 2,289 \\
\hline 해양 ODA & 197 & 243 & 256 & 763 & 3,011 & 3,162 & 1,161 & 564 \\
\hline 수산 ODA & 312 & 282 & 252 & 2,178 & 2,161 & 2,645 & 1,910 & 1,725 \\
\hline 비율(\%) & 0.23 & 0.28 & 0.20 & 0.96 & 1.45 & 1.10 & 0.67 & 0.45 \\
\hline
\end{tabular}

해양수산분야 무상원조실적의 경우, 위의 표와 같이 2005년이후 꾸준히 증가한 바 있으나 타중점사업분야인 보건 $(16.1 \%)$, 교육 $(26.6 \%)$, 농림수산 $(13 \%)$, 공공행정 $(15 \%)$, 산업에너지 (13.1) 에 대비, 해양수산분야 ODA가 차지하는 비율은 상당히 낮은 수준이라 하겠다. (2012년 기준)

3) 수산분야 유상원조사업은 총 1건으로 1997년 앙골라 어선건조사업 (107억원)이 전부임

4) 2012년 대외무상원조실적 통계를 바탕으로 작성하였으며 프로젝트와 초청연수프로그램을 합산하여 산정함 


\section{3. 여수프로젝트의 추진현황 및 시사점}

그간 코이카에서 진행한 해양수산분야 프로그램의 위에서 설명한 바와 전체사업 대비 실적 이 미흡한 측면이 있었으나 2005년이후 해양수산분야 지원실적이 꾸준히 증가하였다는 점과 여수프로젝트 추진을 통해 동 분야의 시급성이 반영된 다양한 주제가 지원가능케 되었다는 점 은 긍정적으로 평가할 수 있겠다. 더불어 여수프로젝트 기획에 있어 지원대상국, 지원분야5), 지원형태의 다양화를 시도, 개발컨설팅사업 요소를 접목시켜 동 분야에 대한 지식기반 체계를 구축한 점은 동 프로젝트의 큰 특징이라 하겠다.

〈표 3-1〉여수프로젝트 연도별 추진현황

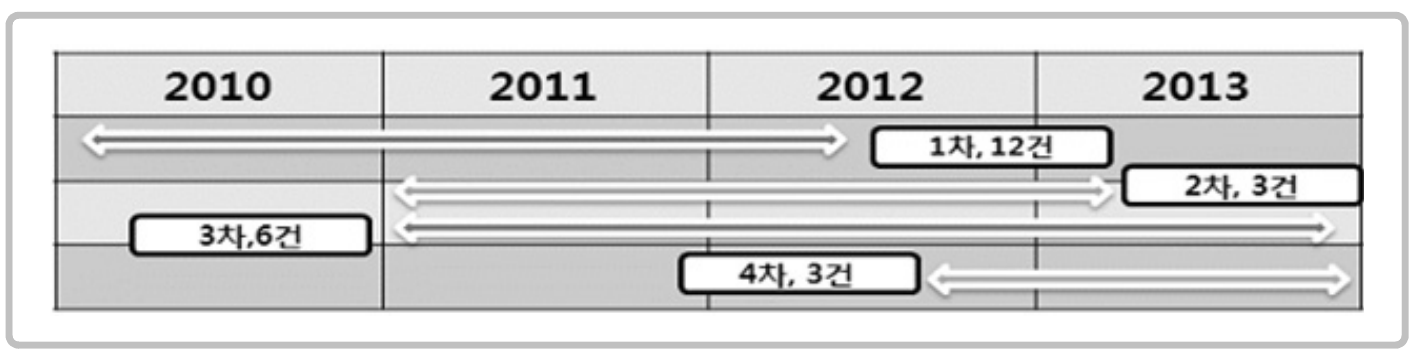

5) 여수프로젝트의 경우 지원분야를 크게 해양환경, 해양자원, 해양산업으로 3가지로 분류하였다.

해양환경분야란, 연안,도서지역을 중심으로 해양환경 및 생태파괴 보전을 위한 해양환경 개선을 말하며 해양오염 대응기 술, 해양 생태계 관리와 보전기술, 해양 환경 탐사 기술, 해양 안전 기술 등이 있다. 해양 자원의 경우, 해양수자원의 실 용화, 해양 생물자원 개발 및 이용기술, 해양 광물자원 탐사 등 해양 자원의 조사, 개발, 이용을 위한 지원을 의미한다. 마지막으로 해양산업의 경우, 해양의 산업화를 위한 지원으로 친환경 수산어업 기술, 물류항만 기술, 해양장비 등이 이에 해당한다. 


\section{가. 1차 사업 (2010-2012)}

\section{〈표 3-2〉여수프로젝트 1차 사업}

\begin{tabular}{|c|c|}
\hline \multicolumn{2}{|r|}{ 1차년도 (2010-2012) } \\
\hline 국가 & 사업명 \\
\hline \multirow{2}{*}{ 인도네시아 } & 인도네시아 연안 및 소도서 환경취약성 지도 작성 (2011-2012/18만불) \\
\hline & 자카르타만 통합연안관리시스템 구축 시범사업 (2011-2012/18만불) \\
\hline \multirow{2}{*}{ 베트남 } & 베트남 해양환경 보존 및 복원 연구 (2010-2011/18만불) \\
\hline & 베트남 해양순환 및 기후변화 연구 (2010-2011/18만불) \\
\hline \multirow{2}{*}{$\begin{array}{c}\text { 남태평양 } \\
\text { (피지,투발루, } \\
\text { 나우루) }\end{array}$} & 남태평양 해양오염 폐기물 처리 (2010-2011/18만불) \\
\hline & 남태평양 해양목장화 사업 (2010-2011/18만불) \\
\hline 필리핀 & 필리핀 연안지역 재해예방 및 위험관리 역량 강화 (2010-2011/18만불) \\
\hline 국가 & 초청연수명 \\
\hline \multirow{5}{*}{$\begin{array}{c}\text { 필리핀 } \\
\text { 인도네시아 } \\
\text { 베트남 } \\
\text { 피지 }\end{array}$} & 친환경 항만운영기술 (2011) \\
\hline & 친환경 수산어업기술 (2011) \\
\hline & 해양목장화 및 연안 생태자원 관리 (2011) \\
\hline & 연안 수산 양식 (2011) \\
\hline & 연안환경 보전 및 재해 대비 모니터링 (2011) \\
\hline
\end{tabular}

\section{1) 중점협력국의 선정}

1 차 사업의 경우 2010 년부터 총 7 건의 사업과 초청연수 5 건이 진행되었다. 1 차사업의 특징 으로는 지원대상국을 기후변화취약국, 해양수산분야 중요협력국, 연안국경제분야 최중요협력 국 등 해양 및 기후변화취약국에 초점을 두어 분류함으로써 기존 무상원조사업에 미포함되었 던 국가들의 지원이 가능하게 되었다는 점이다. ${ }^{6}$.

6) 기존 무상원조체제 하의 지원대상국이 하위중소득국(LMIC)이하 그룹에서 협력국의 소득수준과 MDGs달성도, 거버넌스, 원조수행여건 등을 종합적으로 고려하여 총 26 개국을 선정하고 이러한 중점협력국에 대해 전체 $\mathrm{ODA}$ 의 $70 \%$ 이상을 집 중적으로 지원 함 
〈표 3-3〉여수프로젝트 우선지원국 선정 기준

\begin{tabular}{l|l}
\hline \multicolumn{1}{c}{ 여수프로젝트 우선지원국 선정 기준 } \\
\hline \multicolumn{1}{c|}{ 구분 } & \multicolumn{1}{c}{1 차 사업 } \\
\hline 기후변화취약국 & 투발루, 키리바시, 바누아트 \\
\hline $\begin{array}{l}\text { 해양수산분야 중요협력국/ } \\
\text { 기후변화취약국 }\end{array}$ & 파푸아뉴기니, 피지, 먀샬군도, 나우루 \\
\hline \begin{tabular}{l} 
연안국/경제분야 최중요협력국 \\
\hline
\end{tabular} & 인도네시아, 베트남, 필리핀 \\
\hline
\end{tabular}

피지, 키리바시, 나우루 등 태평양 도서국가들의 경우, 기후변화라는 지구적 환경 문제로 인한 해수면 상승으로 수몰 위기에 직면하고 있고 유엔 등 국제무대에서 기후변화를 태평양 도서국들의 생존을 위협하는 등 안보의 문제와 직결됨에도 불구하고 기존 무상원조체제하에서 는 우선지원대상국에서 제외되어 있어 지원실적이 많지 않았다. 이에 따라 여수프로젝트는 $\mathrm{UNEP} / \mathrm{SOPAC}$ 의 기후변화취약국인 투발루, 키리바시, 바누아트 같은 해수면 상승에 따른 대 표적이 수몰위기국가를 우선지원대상국(10국)으로 선정하여 추진하였다.

\section{2) 지원분야의 수요 분석}

1 차사업의 수요조사 결과, 4 개 공관7)을 통해 7 개국8)에서 총 109 건의 사업이 요청되었다 (연구개발 44건, 초청연수가 65건). 수요분석 결과, 해양환경분야가 총 44 건 중 33 건으로 전 체 대비 $75 \%$ 를 차지(프로젝트 기준), 아래 표〈표 3-4〉와 같이 2개국 이상이 동시에 요청한 11 건의 사업 중 8 건이 해양환경분야로 나타남으로써 동 분야에 대한 협력대상국의 관심이 점 차 증가하고 있음을 알 수 있다. 또한 동 분야 주제도 '폐기물 해양배출 종합관리시스템 구축', ‘해양환경 보전 및 복원 연구', ‘해양오염수 폐기물 처리’ 등으로 다양하며 남태평양국가 뿐만 아니라 동남아시아 권역(베트남)에서도 수요가 존재함을 확인 할 수 있다.

7) 피지, 인도네시아, 필리핀, 베트남

8) 피지, 투발루, 나우루, 키리바시, 인도네시아, 베트남, 필리핀 
〈표 3-4〉1차 사업 수요요청 분석

\begin{tabular}{|c|c|c|c|}
\hline 분야 & 사업요청주제 & $\begin{array}{c}\text { 총 } \\
\text { 신청국 } \\
\text { 수 }\end{array}$ & 신청국 \\
\hline 해양환경 & 폐기물 해양배출 종합관리시스템 구축 & 4 & 베트남, 나우루, 피지, 투발루 \\
\hline 해양환경 & 해양환경 보전 및 복원연구 & 4 & 베트남, 나우루, 피지, 투발루 \\
\hline 해양환경 & 해안 오염 수 해양 폐기물 처리 & 3 & 피지, 투발루, 나우루 \\
\hline 해양환경 & 해양순환 및 기후변화 연구 & 3 & 피지, 투발루, 베트남 \\
\hline 해양환경 & 수몰위기 국가를 위한 해양신공간 개발 & 3 & 피지, 투발루, 나우루 \\
\hline 해양환경 & 어장환경 회복 및 개선기술 연구 & 3 & 피지, 투발루, 나우루 \\
\hline 해양자원 & $\begin{array}{l}\text { 해조류를 이용한 유용물질 (항생물질, 항 } \\
\text { 염증 물질, 바이오에탄올 등) 탐색연구 }\end{array}$ & 2 & 피지, 투발루 \\
\hline 해양자원 & $\begin{array}{l}\text { 어류 및 무척추동물을 이용한 신 생리 } \\
\text { 활성 펩타이드의 정제 및 CDNA 연구 }\end{array}$ & 2 & 피지, 투발루 \\
\hline 해양환경 & 해양 목장화 사업 & 2 & 피지, 투발루 \\
\hline 해양자원 & $\begin{array}{l}\text { 산호삼각지 해양생물의 유전적 분류와 } \\
\text { 가입 모니터링 }\end{array}$ & 2 & 피지, 투발루 \\
\hline 해양환경 & 심해 해양관측부이시스템 개발 & 2 & 피지, 투발루 \\
\hline
\end{tabular}

※ 2개국 이상 수요접수사업 대상으로 수요분석 실시

우리나라의 경우, 폐기물 해양배출 즉 해양쓰레기 관리에 관한 국가기본계획 수립(2008) 및 해양쓰레기 대응센터(2011)를 설치하여 종합적, 과학적 대응을 위해 연구와 정책을 활발히 수행하였고 다양한 해양쓰레기 수거정책을 2006년에서 2010년까지 1,502억원의 예산을 투입, 364,022 톤의 해양쓰레기를 수거 및 처리한 경험이 있다. 특히 조업 중 인양 해양쓰레기 수매 사업은 수거정책은 우리나라의 대표적 정책 중 하나이며 외국의 모범사례로 소개되고 있을 정 도로 국제적으로 인정받은 바, 동 분야에 대한 국제적 경쟁력을 통해 '여수프로젝트-남태평양 해양오염 폐기물 처리사업'을 시작으로 한 해양쓰레기 분야 지원사업을 대상국을 대폭 확대하 여 기술이전을 할 필요성이 있다. 


\section{나. 2차년도 (2011-2013)}

2 차 사업 지원대상국은 대륙별(대서양, 태평양, 인도양)로 나누어 기후변화취약국, 해양오 염심각성, 홍보효과 등을 고려한 15 개국이 선정하였으며 1차년도 지원국가의 유사 및 중복지 원을 지양함으로써 지원대상국의 형평성을 고려하였다. 이에 따라 2 차 사업의 경우 탄자니아, 스리랑카, 그레나다 총 3 국에서 사업이 추진되었다.

〈표 3-5〉 여수프로젝트 2차 사업

\begin{tabular}{c|c}
\multicolumn{2}{|c}{ 2차년도(2011-2013) } \\
\hline 국가 & 사업명 \\
\hline 그레나다 & 그레나다 남해안과 동해안에 관한 연구 (2011-2013/53만불) \\
\hline 스리랑카 & 스리랑카 북부 및 북서부 지역 수산 양식 개발연구 (2011-2013/13만불) \\
\hline 탄자니아 & 잔지바르 양식 개발 타당성 조사 (2011-2013/53만불) \\
\hline
\end{tabular}

1) 중남미국의 확대 지원 필요

2 차 사업의 경우 8 개국9)에서 총 23 개의 사업이 요청되었으며 '해양환경개선' 이 대다수를 차지한 1 차 사업과는 다르게 지원분야 중 '해양산업, 즉 해양의 산업화를 위한 지원으로 친환 경 수산어업 기술' 에 관한 수요가 23건 중 13 건으로 $50 \%$ 이상을 차지, 1 차사업 수요조사 결과 와는 다른 양상을 보인다. 이는 세네갈, 탄자니아 등 아프리카 권역에서는 수산분야가 식량 및 빈곤문제와 직결, 수리남, 과테말라, 탄자니아 등 해양자원 부국인 중남미 권역에서는 어업과 양식이 경제에 주요한 부분을 차지함으로써 해양산업에 대한 중요성이 점차 증가하고 있기 때 문이다.

9) 세인트루시아, 스리랑카, 그레나다, 수리남, 세네갈, 과테말라, 모니타리아, 탄자니아 
〈표 3-6〉2차 사업 수요요청 분석

\begin{tabular}{|c|c|c|}
\hline 국가 & 지원분야 & 요청 내용 \\
\hline 세인트루시아 & 해양산업 & Lobster 어장 관리법 준수 현황 평가 \\
\hline \multirow{3}{*}{ 스리랑카 } & 해양산업 & 북부 및 북서부 지역 수산양식 개발 연구 \\
\hline & 해양자원 & $\begin{array}{l}\text { 경제 및 보건의료적 관점에서의 해저 생태계에 대한 영향력 } \\
\text { 조사 및 Ballast Water 외래동식물상에 대한 연구 }\end{array}$ \\
\hline & 해양환경 & 개발, 보호 및 보존을 위한 연근해 및 섬 생태 환경평가 연구 \\
\hline 그레나다 & 해양환경 & 그레나다 남해안과 동남해안에 관한 연구 \\
\hline \multirow{3}{*}{ 수리남 } & 해양산업 & 수산양식 교육센터 설립 \\
\hline & 해양산업 & 중앙수산시장집결장수리,보수 \\
\hline & 해양산업 & 수리남수산업의부가가치증대 \\
\hline \multirow{3}{*}{ 세네갈 } & 해양산업 & 3개 어종 양식 \\
\hline & 해양산업 & 굴양식 \\
\hline & 해양산업 & Aquarium 타당성 조사 \\
\hline \multirow{7}{*}{ 과테말라 } & 해양환경 & 카리브해 연안 보존을 위한 연구 및 교육 선 운항 \\
\hline & 해양환경 & 카리브해 연안 종합관리정책 시행 \\
\hline & 해양자원 & $\begin{array}{l}\text { "Punta de Manabique, Izabal, Guatemala Wild Life" Refuge } \\
\text { 인공어초 개발 }\end{array}$ \\
\hline & 해양자원 & 태평양 연안 어족 관리 \\
\hline & 해양자원 & 태평양연안산호초개발 \\
\hline & 해양환경 & 산안토니아 석호 복원 및 종합 관리 \\
\hline & 해양산업 & 녹색 항만 운영을 위한 Puerto Quetzal항의 대기 오염 측정 \\
\hline 모리타니아 & 해양환경 & 심해자원 개발시 해양환경 다양성 보전 증진을 위한 기술협력 \\
\hline \multirow{4}{*}{ 탄자니아 } & 해양산업 & 홍합 양식 타당성 조사 \\
\hline & 해양산업 & 연안 양식 증진을 위한 농어 종자 생산 및 공급 \\
\hline & 해양산업 & 진흙게 부화장 개발 \\
\hline & 해양산업 & 잔지바르양식개발타당성조사 \\
\hline
\end{tabular}

위의 표〈3-6〉에 따르면 사업요청국가 중 중남미국의 비율이 $50 \%$ 이상을 차지, 사업주제 또한 해양환경, 보전 및 수산양식 등 다양한 주제의 사업을 요청한바 중남미 권역의 지역적 특 성에 맞는 지원이 필요하다. 중남미 권역은 대부분이 연안국이라는 점, 이로 인해 연안재해취 
약성이 심각한 수준에 이르고 있는 점을 고려하여 해양산업뿐만 아니라 해양환경개선분야, 특 히 연안관리정책에 대한 지원이 확대되어야 할 것으로 보인다.

여수프로젝트에 의해 추진된 '그레나다의 남해안과 동해안에 관한 연구'도 이러한 연안도서 국의 재해취약성 (허리케인 벨트의 가장자리에 위치하고 있어 연안 재해취약성이 심각)을 고 려하여 추진된 사업으로 추후에도 수산분야 (해양산업) 뿐만 아니라 연안관리정책 등, 협력대 상국의 현황에 맞는 전략적인 지원이 필요할 것으로 보인다.

\section{2) 개발컨설팅 요소의 접목}

현재까지 기존 코이카 사업에서 추진되었던 수산부문(여수프로젝트 지원분야 중 주로 해양 산업에 속함) 의 사업을 살펴보면 프로젝트 형으로는 대부분 하드웨어성격이 강한 양식장 건 설 사업이 많았고 그 외에는 초청연수프로그램 등 역량강화 중심으로 진행되었다. 이에 따라 수산분야 사업의 경우 주제 및 형식에 있어 한계점이 있었다.

이를 보완하기 위해 여수프로젝트의 경우 사업의 추진형태 및 내용에 있어 기존의 하드웨어 중심의 프로젝트형 사업과는 차별화하고 컨설팅요소를 접목시켜 다양한 콘텐츠를 포함시켰다.

첫 번째 탄자니아 '잔지바르 양식 개발 타당성 조사의 경우, 탄자니아 잔지바르의 해면양식 개발타당성, 양식 적지 선정 및 잔지바르에 적합한 양식장 모델을 제시함으로써 탄자니아 잔 비자르 양식개발 로드맵을 작성하였다. 동 사업의 가장 큰 특징은 '잔지바르 양식연구센터' 설 립을 위한 타당성과 기본계획이 도출되었다는 점이다. 연구센터의 건립여건 검토기준, 설계지 침, 사업지 건설환경 현황 및 대상 부지 분석 등을 통해 정책제안을 시작으로 구체적인 시행방 안까지 마련하였다.

두 번째 그레나다 '남해안과 동남해안에 관한 연구' 의 경우 통합적 연안관리체제의 구축 및 기반강화를 위해 연안관리분야 전문가 파견 및 장비를 지원하고 이론과 현장실습이 동시에 가 능토록 하였다. 동 사업을 통해 그레나다에 연안관리정책의 방향을 제시하고 연안관리방향별 세부 추진과제를 도출하였다. 이 중 기후변화 및 재해대응력 강화 부문의 경우, 연안재해취약 성평가와 같은 과학적 분석을 기반을 통한 대응방안을 마련이 제시하였는데 이는 그레나다의 연안의 취약성 개선에 큰 도움이 될 것으로 사료된다. 재해대응력 강화를 위해 그레나다 해당 지역의 여건과 적용기술의 효과 등을 고려하여 인공어초를 활용한 Barrier설치, 지오튜브 설 치, 산호초 및 맹그로브를 활용한 자연적 방호력 증대 등을 제시, 이를 위한 시행방안까지 도 출되어있어 추후 정부 및 국제협력을 통해 지속가능한 지원이 가능토록 하였다. 


\section{다. 3차년도 (2011-2013)}

여수프로젝트 3 차 사업은 해양분야 관련 국제기구와의 협력을 통한 다자협력이다.

현재 우리나라가 국제기구에 가입하여 활동하고 있는 해양관련 국제기구 및 지역해 프로그램 은 세계기상기구 (WMO), 정부간해양학위원회 (IOC), 국제해저기구 (ISA), 북태평양해양과학기 구 (PICES), 동아시아해역조정기구 (COBSEA), 북서태평양보전실천계획 (NOWPAP) 등이 있으 나 일부기구만이 활발하게 활동, 그 외 기구는 정부차원의 지원이 지속적으로 이루어지지 않아 참여현황이 미흡한 상황이다. 이러한 상황 하에서 추진된 여수프로젝트를 통한 국제기구와의 협력은 해양관련 다자협력의 중요성과 국제사회의 동향을 파악할 수 있는 계기를 마련하였다10).

\section{〈표 3-7〉 여수프로젝트 3차 사업}

\begin{tabular}{c|c}
\hline \multicolumn{1}{|c}{ 3차년도 (2011.12-2013) } \\
\hline 국제기구 & 사업명 \\
\hline $\begin{array}{c}\text { UNEP- } \\
\text { COBSEA }\end{array}$ & 동아시아 지역해의 연안 침식과 해수면 상승 대책 적용 (2011-2013/40만불) \\
\hline PEMSEA & $\begin{array}{l}\text { 항만안전 보건 환경 법 개발 및 적용을 통한 지속가능한 운영 } \\
\text { (2011-2013/45만불) }\end{array}$ \\
\hline WCPFC & 태평양고도회유성어종관리 (2011-2012/22만불) \\
\hline FAO & 지속가능한 수산을 위한 불법 어업대처 능력 배양 (2011-2013/45만불) \\
\hline IOC & 유해적조종에 대한 연구 및 아프리카 지역협력 강화사업 (2011-2013/31만불) \\
\hline IMO & 태국근해 유류 오염 방지을 위한 환경취약성 지도작성 (2011-2013/40만불) \\
\hline
\end{tabular}

\section{1) 해양분야 국제사회의 동향 파악}

$\mathrm{KOICA}$ 는 국제기구 협력사업을 위해 2011년 2월 3월까지 수요조사를 실시, 8개 기구에 16 건의 사업요청서를 접수받았다. 수요조사 결과, 해양환경분야가 16 건 중 8 건으로 $50 \%$ 를 차지 하였으며 해양환경분야 중 유류오염대응기술, 항만안전 등 '해양환경개선'분야와 산호생태계 보호, 산호초 유기체 분류 등 ‘해양생태계 관리와 보전기술'에 관한 수요가 많은 비중을 차지 했다. 이로써 현재 국제사회에 집중되는 관심이 현재 기후변화와 해양영향, 재해 대응, 해양생 태계 보존 등에 집중되어 있다는 점을 파악할 수 있다.

10) 동 프로젝트을 위해 1 달간의 수요조사를 실시. 국제기구의 사업요청서를 접수하여 국토부 (현 해양수산부), 농림부 (현 농림축산식품부) 등 관계부처, 해양관련 전문가 그룹과 협의를 통해 해사, 수산, 해양환경 분야 등 6 개 핵심 국제기구를 선정함 
〈표 3-8〉3차 사업 수요요청 분석

\begin{tabular}{c|l|l}
\hline 국제기구 & 지원분야 & \multicolumn{1}{|c}{ 요청 내용 } \\
\hline UNEP-COBSEA & 해양환경 & 동아시아 지역해의 연안 침식과 해수면상승 대책 적용 \\
\hline IMO-PEMSEA & 해양환경 & 태국근해 유류 오염 방지 \\
\hline WCPFC & 해양자원 & 태평양 고도회유성(참치) 어종 관리 \\
\hline PEMSEA & 해양환경 & $\begin{array}{l}\text { 항만 안전 보건 환경 법 개발 및 적용을 통한 지속가능한 } \\
\text { 운영 }\end{array}$ \\
\hline IOC & 해양자원 & $\begin{array}{l}\text { 유해적조종의 유전적 가변성과 유독성, 개체군 역학, 생물 } \\
\text { 지리학간의 관계에 대한 지역 협동 평가 }\end{array}$ \\
\hline UNEP-COBSEA & 해양환경 & Green Fins를 통한 개도국 산호생태계 보호 \\
\hline PICES & 해양환경 & 북태평양의 기후 가변성과 변화에 대한 이해 \\
\hline FCPFC & 해양산업 & $\begin{array}{l}\text { 통합 어업 관리 및 해상 옵서버 데이터 직접 입력 타당성 } \\
\text { 시험 }\end{array}$ \\
\hline PICES & 해양환경 & $\begin{array}{l}\text { 개도국의 불법어업 (IUU) 근절 및 지속가능한 솨경규모어업 } \\
\text { 을 위한 평양 지역의 주요 스트레서에 대한 생태계 반응 분석 }\end{array}$ \\
\hline PICES & 해양환경 & 여수 - 사회와 이해도모를 위한 생태계 관찰 \\
\hline IOC-WESPAC & 해양자원 & 서태평양 산호초 유기체의 DNA 분류 및 모니터링 \\
\hline PEMSEA & 해양환경 & Blue Economy 로드맵 확대 적용 \\
\hline
\end{tabular}

국제기구를 통한 다자협력은 해양분야 국제사회의 동향 및 각국의 정책기조를 파악하는 동 시에 해양분야 네트워크를 형성할 수 있다는 측면에서 상당히 중요하다.

현재 미국과 EU가 우리나라 원양어선의 불법적 행위를 적발, IUU 어업 가담국가로 지정하 는 등 국제사회에 비난의 목소리가 높아지는 가운데, 여수프로젝트를 통해 추진된 FAO 사업 "개도국의 불법어업 (IUU11)) 근절 및 지속가능한 소규모어업을 위한 책임있는 어업관리 추진" 의 경우, 프로젝트를 통해 개도국에 항구국조치협정(PSMA), 국제어선등록시스템(Global Record) 및 지속가능한 소규모 어업 발전을 위한 국제치침 (VG-SSF) 등 IUU어업 근절을 위 한 국제프로그램에 직접 참여함으로써 국제사회의 현안사항에 한국의 관심 및 참여를 보여주 었던 사례라 사료된다.

11) IUU란 Illegal, unreported, unregulated(불법, 비보고, 비규제) 어업으로 무허가어업 또는 어업활동에 관한 국내외 법규 및 의무를 위반한 어업활동, 국가 또는 국제수산기구에 보고의무를 이행하지 않거나 거짓 보고하는 어업활동, 공해 또는 국제수산기구 관할 수역에서 무국적 어선을 이용한 어업활동, 또는 국가책임과 불일치하게 행하는 어업활동을 말한다. 


\section{2) 해양분야 아프리카 지역협력 강화 지원 (해양연구 외 활동)}

3 차 국제기구 협력사업은 대부분 연구를 중심으로 이루어져 있으나 'IOC 유해적조종에 대 한 연구 및 아프리카 지역협력 강화사업'의 경우 연구뿐만 아니라 해양분야 아프리카 지역협 력 체계 지원활동을 수행하였다. 동 사업은 IOC 총회 Resolution XXVI-3에 의거, UNESCO 와 IOC가 채택한 최우선 사업으로 선정할 정도로 시급성 및 중요성의 비중이 높았으나 한국뿐 만 아니라 국제적 지원이 미흡한 실정이었다.

이에 동 프로젝트는 아프리카 36 개국을 회원국으로 하는 IOC AFRICA 지역위원회 설립을 지원12)하고 2차례 아프리카 지역위원회 회의개최를 개최, 이를 운영할 수 있도록 하는 로드맵 수립과 더불어 아프리카 내 관련 교육 실태 점검을 통해 해양과학 전문가 양성을 위한 기초자 료 구축 및 향후 전문가 육성 방안을 도출하는 등 IOC Africa를 지속적으로 운영하고 아프리 카지역의 해양 과학 역량 강화에 기여 나갈 수 있는 발판을 마련하였다.

\section{라. 4차년도 (2012-2013)}

4 차사업의 경우 1 차 지원대상국을 우선지원국으로 선정하여 여수프로젝트의 사업성과 확산 및 동 프로젝트의 지속가능성을 검증할 수 있도록 하여 1차 사업 중 평가결과가 우수한 사업 을 후속사업으로 선정하여 추진하였다. 이에 따라 1차 사업 지원대상국인 인도네시아, 필리핀, 베트남, 피지, 나우루, 투발루에 진행한 사업 중 4차 사업으로는 필리핀, 베트남, 인도네시아 3 국의 사업 선정, 현재 총 3 건이 진행 중이다.

\section{〈표 3-9〉여수프로젝트 4차 사업}

\begin{tabular}{l|l}
\multicolumn{1}{c}{ 4차년도(2012-2013) } \\
\hline \multicolumn{1}{c|}{ 국가 } & 사업명 \\
\hline 베트남 & 베트남 해양순환 및 기후변화 연구 ॥ (2012-2013/28만불) \\
\hline 인도네시아 & 자카르타 연안통합관리 체계구축 연구 ॥ $(2012-2013 / 28$ 만불 $)$ \\
\hline 필리핀 & 필리핀 연안지역 재해예방 및 위험관리역량강화 ॥ $(2012-2013 / 28$ 만불 $)$ \\
\hline
\end{tabular}

12) 회원국 : 앙골라, 카메룬, 베넹, 콩코, $\mathrm{DR}$ 콩고, 이집트, 가나, 기니, 케냐, 모잠비크, 나이지리아, 세네갈, 남아공, 수단, 토 고, 코티드부아르, 나미비아, 에티오피아, 가봉 등 
1) 현지공동연구팀 구성을 통한 맞춤형 컨설팅 지향

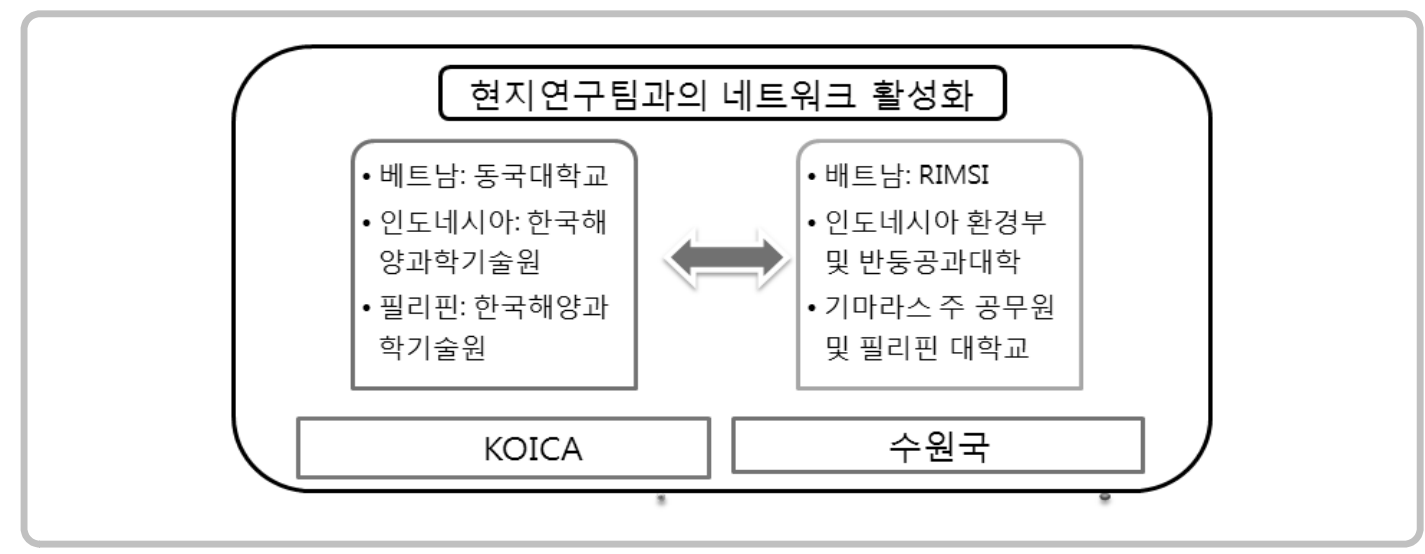

4차 사업 3건 모두 현지공동연구팀을 설정, 협력국이 연구에 직접 참여할 수 있도록 유도, 수원국의 참여율을 높였다. 인도네시아의 경우 환경부 및 반둥공과대학(Institute of Technology Bandung : ITB)에 연구팀을, 필리핀 사업은 기마라스 주 공무원과 필리핀 대학교 연구진을 투입하여 공동연구를 추진하고 협력대상국의 환경, 사회, 경제적 측면의 이해도를 높였다. 4 차 사업 중 '인도네시아 자카르타 연안통합관리 체계구축 연구 II'는 현지연구팀 통해지반침하 에 대한 실제적인 정량자료를 확보, 지반침하의 원인과 다양한 인자를 파악하여 사회경제적 비용편익분석을 실시, 향후 동지역 연안 관리 정책에 바로 적용 가능한 결과를 도출하였다.

\section{2) 역량강화프로그램 강화}

여수프로젝트 4차의 경우, 초청연수프로그램 외 현지연구팀을 대상으로 한 교육프로그램 및 워크샵 등을 실시, 현지 공무원 및 연구진 역량강화에 초점을 맞추어 활동을 수행하였다.

필리핀 재해예방 및 위험관리역량강화 II의 경우, 초청연수를 통한 공무원 교육뿐만 아니라 기마라스 주 지역 주민들을 대상으로 한 맞춤형 교육을 실시하여 커뮤니티 의견을 반영한 결 과를 도출토록 하였으며 베트남 해양순환 및 기후변화연구 II의 경우, 현지 학생 및 연구자들 을 대상으로 한 해양단기프로그램을 실시, 기후변화와 연안적응 관련 연구 동향 및 적응 계획 수립방법 등의 교육을 통해 해양분야에 대한 폭넓은 교육의 장을 마련하였다. 마지막으로 인 도네시아 사업의 경우, 현지조사 이후 자료처리 및 분석을 통한 결과도출을 위해 인도네시아 환경부 공무원을 대상으로 3차례 자료처리 교육프로그램을 실시, 사업종료 후에도 협력국 자 체적인 사업수행이 가능토록 역량을 도모하였다. 


\section{4. 맺으며}

마지막으로 상기 여수프로젝트 추진 현황을 통해 향후 해양수산분야 ODA사업 추진 시 고려 해야 할 사항을 정리하면 아래와 같다.

우선 동 보고서를 통해 2010년부터 2013년까지 추진된 여수프로젝트 (1차-4차)의 추진현황 및 주요성과를 들자면 1차 사업을 통해 지원대상국을 남태평양 국가로 확대하고 지원분야의 다양한 수요파악이 될 수 있었으며 2차 사업은 마스터플랜수립, 사전타당성조사 등 개발컨설 팅사업 요소를 반영하여 해양수산분야의 지식기반형 ODA 사업의 토대를 마련하였고 3차 사 업에서는 국제기구와의 협력을 통해 해양분야 국제사회의 동향 및 각국의 정책기조를 파악하 는 동시에 해양분야 네트워크를 형성할 수 있었다. 마지막으로 4차 사업을 통한 현지공동연구 팀 설정 및 역량프로그램의 요소를 포함, 협력국의 주인의식을 높여 맟춤형 원조를 지향할 수 있었고 특히 1 차 후속사업으로서의 여수프로젝트의 확대 및 지속가능성을 보여준 것은 큰 장 점이라 평가된다.

여수프로젝트의 주요성과를 바탕으로 향후 해양수산분야 ODA사업이 동 성과를 지속적으로 거두기 위해서는 아래와 같은 점이 중점적으로 고려될 필요가 있다.

첫째, 지원대상국 (남태평양 도서국) 및 해양자원분야의 확대지원이 필요하다. 여수프로젝 트를 통해 해수면 상승으로 수몰위기에 처한 피지, 투발루, 나우루, 키리바시 등 남태평양국가 와 그레나다, 탄자니아 등 중남미 및 아프리카 권역을 대상으로 지원국을 확대할 수 있었으나 여전히 동 분야의 $\mathrm{ODA}$ 사업은 베트남, 필리핀, 인도네시아 등 아시아 국가에 중점 지원되고 있는 실정이다. 여수프로젝트 1차 수요조사 결과 남태평양국가에서 요청된 프로젝트 수는 총 32 건으로 1 차 사업 총 요청건수의 $70 \%$ 이상에 해당되어 잠재적 수요가 높고 지리적으로 풍부 한 해양자원과 남극에 대한 접근 용이성 및 원양어업 등 주요 경제 전략요충지인 바, 인도주의 적 지원뿐만 아니라 경제분야 측면에서의 전략적인 지원이 필요하다.

더불어 현재까지 추진된 여수프로젝트의 분야가 대부분 해양환경 및 해양산업에 집중되어 있는 바, '해양자원 분야-해양수자원의 실용화, 해양 생물자원 개발 및 이용기술, 해양 광물자 원 탐사 등 해양자원의 조사, 개발, 이용'에 관한 협력대상국의 인식 증대 및 확산이 필요할 것으로 사료된다. 
둘째, 해양수산분야의 창의적인 프로젝트를 적극 발굴 (어촌 새마을운동 전수사업)해야 한 다. 그동안 많은 선진국들이 ODA사업을 통해 개도국의 연안자원의 회복과 지속가능한 개발을 위하여 해양보호구역(MPA : Marine Protected Area), 연안통합관리(CZM : Coastal Zone Management) 등의 사업을 지원한 바 있으나, 선진국에서 시행하고 있는 제도를 축소 및 간 편화하는 일방적인 전달에 그쳐 실패한 사례가 많았다.

따라서 제도 수립에 앞서 협력대상국 의식개선사업 (어촌 및 연안어장 환경개선 운동), 어장 의 폐어망 및 쓰레기 가져오기 운동(어망의 주인표시), 마을의 청소운동, 불법어업 감시운동 (명예감시자 및 감시선박 공동구입/운영)을 통해 수원국의 주인의식을 고취시키고 소득증대사 업(마을 공동어장사업(공동생산, 공동판매) 시행, 마을 공동의 금어기 설정, 생태관광사업 발 굴 및 공동시행 등)과 연결시켜 수원국의 참여율을 높여야 한다.

우리나라 어촌에는 새마을운동의 주인의식, 참여의식, 공동체의식을 기본으로 한 자율관리 공동체 육성사업을13) 2002년부터 추진하여 지속가능한 어장환경과 소득증대가 동시에 가능토 록 추진하고 있다. 그러므로 우리나라의 어촌 새마을운동의 경험과 노하우를 협력대상국의 사 회 문화 정치적 맥락을 충분히 파악하여 연안자원의 지속가능한 개발과 소득증대사업과 연결 될 수 있는 다양한 프로그램을 발굴하여야 한다.

마지막으로 해양수산분야의 개발컨설팅 사업 확대를 통해 향후 해당 국가 또는 정부의 중장 기 정책수립 및 제도 구축에 영향을 미칠 수 있도록 다양한 지식기반형 사업을 발굴해야 할 것 이다. 우리나라 해양분야의 경우 종합해양행정체제를 구축, 운영한 경험이 있고 연안통합관리 제도, 연안공간관리, 연안해양관리 법제도 및 관리기술 등은 국제사회로부터 그 우수성을 인 정받은 바 있다. 더불어 수산분야의 경우, 해수면 양식업 생산량이 130 만 톤에 이르는 세계 4 위의 양식 선진국으로 친환경 양식에 관한 경험 및 기술이 농축되어 글로벌 수준의 수산분야 전문가 역량을 갖추고 있다고 사료된다. 양식산업의 경우 협력대상국에 수산물 및 부가가치 상품수출을 통한 소득증대에 기여할 수 있고 이에 따른 고용창출이 가능하기 때문에 동 분야 에 대한 수요가 점차 증가하고 있는 바, 이에 관한 컨설팅 사업을 확대할 필요가 있다.

여수프로젝트는 박람회 역사상 최초의 해양분야 국제협력프로그램이자 여수선언을 실행하 는 구체적 행동계획이라는 점에서 그 중요성과 의미가 크다. 동 사업의 결과가 다양한 방식의 후속사업과 효과적으로 연계될 수 있도록 $\mathrm{KOICA}$ 및 관계부처의 지속적인 관심과 지원을 기대 한다.

13) 2002년부터 추진하고 있는 자율관리 공동체 육성사업은 어업인 스스로가 수산자원을 조성하고 관리할 수 있도록 지율 관리어업 공동체를 구성, 수산자원조성(전복·해삼 등) 증대, 친환경적 어업, 환경개선 등 지속적 이용이 가능한 어장환 경과 소득증대 공동기반을 조성해 부자어촌 만들자는 취지로 시작됨 


\section{참고문헌}

국제개발협력위원회 (2012). 개발컨설팅 ODA 사업 종합 평가결과, 제 12 차 국제개발협력위원회 안건.

$\mathrm{KOICA}$, 여수재단, 국립수산과학원

여수프로젝트 탄자니아 잔지바르 해면 양식개발 타당성 조사사업 최종보고서 (2103.2)

$\mathrm{KOICA}$, 여수재단, 한국해양수산개발원

여수프로젝트 그레나다 남해안과 동남해안에 관한 연구 최종보고서 (2013.2)

국토해양부 (2009). '제2차 해양수산발전기본계획 수립연구' .

경남발전연구원 채동렬 (2012). '해양쓰레기로 인한 어업자원관리의 문제와 피해저감 방안 ' 국토연구원 (2009). '국제협력업무가이드북

한국해양연구원 (2011). 중남미 국가와 해양자원 공동연구

한국해양수산개발원 (2011), 해양수산분야 공적개발원조 확대를 위한 국가전략 연구 (I)

〈인터뷰〉

어촌 새마을운동 사업 방안에 관해 한국해양대학교 조동오 교수 (2013.10.10 